\title{
Delineation of Nocardia farcinica by Delayed Type Skin Reactions on Guinea Pigs
}

\author{
By M. MAGNUSSON AND F. MARIAT \\ Tuberculin Department, Statens Seruminstitut, Copenhagen, and \\ Institut Pasteur, Paris \\ (Accepted for publication 28 September 1967)
}

\begin{abstract}
SUMMARY
An immunological method based on the specificity of delayed-type skin reactions on guinea-pigs has been used for comparing 17 Nocardia strains. By this method, 4 isolates labelled Nocardia farcinica, four labelled $N$. asteroides and I strain labelled $N$. blackwellii could be grouped together with the type strain of $N$. farcinica. Three other strains labelled $N$. farcinica were clearly distinct from this group of 10 strains. A strain of $N$. asteroides used previously as reference strain for this species was clearly distinct from the $N$. farcinica strains, and this applied also to a recently proposed reference strain of $N$. asteroides. A strain of $N$. brasiliensis was clearly distinct from all the other strains, while the results obtained with a strain received without species designation were inconclusive. On this basis, the authors consider that all the Io strains, which form a homogeneous group, should be classified as $N$. farcinica. The 3 other strains labelled $N$. farcinica should be classified into 2 other species. Nocardia asteroides would seem to be a separate species.
\end{abstract}

\section{INTRODUCTION}

In I 888 Nocard reported the isolation of a micro-organism which caused farcy in cattle in Guadeloupe (Nocard, I888). The following year Trevisan described this organism under the name Nocardia farcinica (Trevisan, 1889). Based on a study of a culture (laboratory no. 752; see Table I) believed to be Nocard's original and a similar strain (753) isolated and identified by Dr C. P. Fitch (New York) Waksman (I957) gave a more recent description of this species. Strain $\mathbf{7 5 2}$ is the type strain of N. farcinica (Sneath \& Skerman, 1966).

Eppinger in 189I described a new pathogenic micro-organism Cladothrix asteroides which was isolated from a man and which caused 'pseudotuberculosis' (Eppinger, I89I): this organism was named Nocardia asteroides by Blanchard (1896). A more recent description of $N$. asteroides is given by Waksman (1957). As an ad hoc reference strain of $N$. asteroides, strain 809 has recently been proposed (Sneath \& Skerman, I966).

Ørskov (I923) found differences between Nocardia farcinica (one isolate) and $N$. asteroides (three isolates) in morphology, and Erikson (1935), studying the same strain of $N$. farcinica as did Ørskov but two other strains of $N$. asteroides, later confirmed those observations. According to Waksman (1957), N. farcinica and N. asteroides can be distinguished by the colour of the vegetative mycelium. Mariat (1963) found some differences between $N$. farcinica and $N$. asteroides as regards capacity for synthesizing urease. On the other hand, in 1962 Gordon \& Mihm published an expanded des- 
cription of $N$. asteroides based on 142 strains, in which the 2 strains of $N$. farcinica mentioned above ( $75^{2}$ and 753 ) could not be distinguished from those of $N$. asteroides by any of the observations or tests used.

Silvestri, Turri, Hill \& Gilardi (1962) also referred Nocardia farcinica 752 to the same cluster ('sphere XI') as some strains of $N$. asteroides, including strain 809 mentioned above. However, this sphere XI also contained strains of several other species of Nocardia and one strain of Mycobacterium phlei (NCTC 8I5I). It is therefore probable that this sphere does not represent a single species in the sense in which this term has been used previously by other authors but is rather a taxon at a higher level. Thus it is not quite clear from previous studies whether $N$. farcinica and $N$. asteroides are, in fact, one or two species.

An immunological method, based on the specificity of the delayed type of skin reaction in guinea pigs, has been useful for classification of mycobacteria, and particularly for identification of species within this genus (Magnusson, 196I, I965, Magnusson, Engbæk \& Bentzon, I96I). By further application of this method on eight strains, it was found that distinction between Nocardia asteroides and $N$. brasiliensis was possible (Magnusson, 1962). The purpose of the present work was to see whether strains classified by other laboratories as $N$. farcinica and $N$. asteroides can be distinguished in the same way.

\section{METHODS}

Organisms. Strains classified as Nocardia farcinica or $N$. asteroides in various bacteriological laboratories or hospitals were included in the study, together with a strain of $N$. brasiliensis for comparison purposes. The origin and source of all the organisms used are shown in Table I. Strain $75^{2}$ is the type strain of $N$. farcinica, authentic co-type (Sneath \& Skerman, 1966).

The cultures were maintained on Sauton medium in $250 \mathrm{ml}$. flasks at $38^{\circ}$ and subcultured monthly.

Condition for growth and harvest. Cultures were inoculated by loop into $180 \mathrm{ml}$. Sauton medium in a $250 \mathrm{ml}$. flask and incubated at $38^{\circ}$. The cultures were incubated for 3-Io weeks, depending on the growth rate, and sterilized by heating in flowing steam for I hr. The organisms were harvested by paper filtration.

Immunological method. The experimental procedure was the same as that described previously (Magnusson, 196I ; Magnusson et al. 196I), except for an amended method of sensitizing the guinea pigs and, in some cases culture filtrates instead of purified sensitins were used for the skin tests.

Sensitization of guinea pigs. One hundred and forty-eight albino guinea pigs (350-600 g.) were sensitized by intradermal injection of dried heat-killed organisms in liquid paraffin (Bayol 55). Each animal was given four simultaneous injections, each of $0 . \mathrm{I} \mathrm{ml}$, of a suspension containing $0.4 \mathrm{mg}$. dried bacteria $/ \mathrm{ml}$.

Skin tests. Intradermal tests were done 3-4 weeks after sensitization, by using dilutions of filtrates of heat-sterilized cultures (cf) or purified sensitins (RS) prepared by a procedure similar to that used for tuberculin purified protein derivative. The culture filtrates were diluted $\mathrm{I} / 50$ and $\mathrm{I} / 500$ with isotonic phosphate-buffered saline $(\mathrm{pH} 7 \cdot 38)$ containing $0.01 \%$ chinosol and $0.005 \%$ Tween 80 (Magnusson et al. 1958). Purified sensitins were used in doses of $2 \mu \mathrm{g}$. and $0.2 \mu \mathrm{g} . / 0 . \mathrm{I} \mathrm{ml}$. of the same diluent. Each injection consisted of $0.1 \mathrm{ml}$. 


\section{Table I. Strains studied}

Laboratory no.

80

$8 \mathrm{I}$

84

85

I 17

650

677

678

745

746

749

750

$75 \mathrm{I}$

752

787

809

Name when received, source* and culture collection numbers

Nocardia sp. ssC 26I. Originally isolated from a Danish patient by Dr P. Holm, Statens Seruminstitut, Copenhagen. PH r84/45-46

Nocardia asteroides SsC 262 . Originally isolated from a chicken by Dr O.J. Mayfield, D.V.M., Charles City, Iowa, U.S.A. EM 9935. M०CL 93. RG 404

$N$. asteroides $\mathrm{PH} 598 / 5 \mathrm{I}-52$. Originally isolated from placenta of a cow, see Case II in Fey et al. (1954)

$N$. asteroides $\mathrm{PH} 599 / 5 \mathrm{I}-52$. Originally isolated from a dog, see Case I in Fey et al. (1954)

$N$. brasiliensis RG 774A. Originally isolated from a submandibular abscess (Gordon \& Mihm, I959). MoCL 254

$N$. asteroides RG 784. Received at the NCTC, London, in June I 944 from N. F. Conant, Duke University Medical Center, Durham, North Carolina, U.S.A. NCTC 676I

N. farcinica G 396. IP 396

N. farcinica G 397. IP 397

$N$. asteroides E. Originally isolated from a Swedish patient (Bergström et al. I966)

$N$. farcinica 378 . Originally isolated from cattle at the Laboratoire élevage Curasson, Dakar. ATCC I378I. IP 378

$N$. farcinica 736. Originally isolated from cattle with farcy at the Farcha Laboratory, Fort-Lamy, Chad. IP 736.

$N$. farcinica 740. Originally isolated from cattle with farcy at the Farcha Laboratory, Fort-Lamy, Chad. IP 740

$N$. farcinica 744. Originally isolated from cattle with farcy at the Farcha Laboratory, Fort-Lamy, Chad. IP 744

$N$. asteroides RG 33I8. Originally isolated from cattle with farcy by Nocard (Waksman, 1957). Type strain of $N$. farcinica, authentic co-type, see Sneath \& Skerman (1966). ATCC 3318. NCTC 4524

N. asteroides RG 3399. Originally isolated by Dr C. P. Fitch, New York, U.S.A. (Waksman, 1957). ATCC 3399

N. blackwellii MoCL 8I. Originally isolated from a foal (Erikson, 1935). ATCC 6846. NCTC 630. RG 503

$N$. asteroides $\mathrm{RG} 727$. Originally isolated from sputum from a patient named Jackson by Dr W. M. Bowman, Georgia State Department of Public Health. Proposed as reference strain of $N$. asteroides (Sneath \& Skerman, 1966).

* Cultures labelled SSC were received from Dr H. C. Engbæk, Statens Seruminstitut, Copenhagen, Denmark; those labelled PH were received from Dr P. Holm, Statens Seruminstitut, Copenhagen, Denmark; those labelled RG were received from Dr Ruth Gordon, Institute of Microbiology, Rutger's State University, New Brunswick, New Jersey, U.S.A.; those labelled G were received from Dr Guilhon, Ecole Vétérinaire, Alfort, France; the one labelled E was received from Dr L. Edebo, Department of Bacteriology, University of Uppsala, Sweden, and the one labelled $\mathrm{McCl}$ from $\mathrm{Dr}$ N. M. McClung, Department of Bacteriology, University of Georgia, Athens, Georgia, U.S.A.

ATCC, American Type Culture Collection, Rockville, Md., U.S.A.; EM, Dr C. W. Emmons, National Institute of Allergy and Infectious Diseases, Bethesda, Md., U.S.A.; IP, Institut Pasteur, Paris, France; NCTC National Collection of Type Cultures, London, England.

Experimental design. The data presented here were drawn from a series of $\mathrm{I} 6$ studies. In most cases the experimental design of the single studies was one of those described previously (Magnusson et al. 196I), 5 strains being compared with each other, or each of 4 strains compared with each of 4 other strains. However, results were also drawn from one study in which Io strains were compared with each other, and from another in which each of 9 strains was compared with each of 9 other strains. In the two latter studies only the highest concentration of each sensitin was used. 
Reading of reactions. The reactions were read after $24 \mathrm{hr}$ and the longitudinal and transverse diameters of erythema recorded in millimetres. Each reaction was read by two readers. To avoid bias in reading the reactions, the dilutions were labelled by code.

Calculation of specificity differences ( $s p d)$. Using averages of the reading of both readers, the difference in specificity of two sensitins was calculated as the difference between the homologous and the heterologous reactions as follows: spd $=\left(A_{a}+B_{b}\right)-$ $\left(A_{b}+B_{a}\right)$, where $A_{a}$ is the average homologous reaction obtained with sensitin $A$ in animals sensitized with strain $a . A_{b}$ is the average heterologous reaction obtained with sensitin $A$ in animals sensitized with strain $b, B_{b}$ and $B_{a}$ denote the average homologous and heterologous reactions with $B$ sensitin. Examples of the calculation have been published previously (Magnusson, 196I).

Each spd value reported below is the average of four determinations. In previous studies (Magnusson, I96I, Magnusson et al. 196I) where the same technique has been used, the standard deviation was $I \cdot I-I \cdot 4 \mathrm{~mm}$. for spd $\leqslant 3 \mathrm{~mm}$. and $2 \cdot 0-2 \cdot 2 \mathrm{~mm}$. for spd $>3 \mathrm{~mm}$.

\section{RESULTS}

The results of calculation of the specificity differences (spd) are shown in Table 2; sensitins showing spd $\leqslant 3 \mathrm{~mm}$ are grouped together. The largest group contains Io sensitins, including preparations from strain 752 , which presumably originates from Nocard, and four other strains $(749,750,75 \mathrm{I}, 753)$ designated Nocardia farcinica as received. Sensitins from three strains $(84,85,787)$, isolated from a cow, a dog and a

\section{Table 2. Specificity differences of sensitins}

The table shows the differences (in $\mathrm{mm}$.) between homologous and heterologous reactions to intradermal tests in guinea pigs sensitized with the strains used for preparation of the sensitins. Italicized figures were published previously (Magnusson, 1962).

Strain

Sensitin

\begin{tabular}{|c|c|c|c|c|c|c|c|c|c|c|c|c|c|c|c|c|c|c|}
\hline \multirow{2}{*}{\multicolumn{2}{|c|}{ Strain }} & \\
\hline & & $\begin{array}{l}\text { + } \\
2\end{array}$ & $\begin{array}{l}n \\
\infty \\
\dddot{q}\end{array}$ & $\underset{⿱ 乛}{\stackrel{N}{\sigma}}$ & 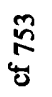 & $\frac{a}{\frac{9}{d}}$ & $\frac{\circ}{2}$ & $\frac{n}{2}$ & 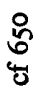 & 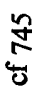 & $\stackrel{\substack{\infty \\
\hdashline}}{0}$ & $\begin{array}{l}\infty \\
\infty 2 \\
2\end{array}$ & $\underset{\substack{0 \\
0}}{\infty}$ & $\underset{⿱ 乛 龰}{\stackrel{+}{J}}$ & $\underset{0}{5}$ & $\begin{array}{l}\infty \\
\infty \\
2\end{array}$ & $\begin{array}{l}8 \\
\infty \\
0 \\
0\end{array}$ & $\Xi$ \\
\hline${ }^{*}$ RS 84 & Nocardia asteroides & - & 0 & 2 & $\mathbf{I}$ & 0 & $-I$ & 0 & 3 & 3 & 2 & 4 & 12 & I5 & 13 & 13 & 3 & 14 \\
\hline RS 85 & $N$. asteroides & 0 & - & 2 & 3 & 一 & - & 一 & -2 & 2 & - & 5 & - & - & - & $I I$ & - & - \\
\hline †cf 752 & N. farcinica & 2 & 2 & 一 & 3 & 0 & $\mathbf{I}$ & 3 & - & 3 & I & 2 & I I & - & 6 & I I & 6 & - \\
\hline cf 753 & N. farcinica & $\mathbf{I}$ & 3 & 3 & - & $\mathbf{I}$ & 0 & 0 & - & - & 2 & 3 & 14 & - & I I & 13 & 6 & 一 \\
\hline cf & N. farcinica & 0 & - & 0 & I & - & -2 & $\mathbf{I}$ & - & 一 & 2 & 3 & I4 & - & I I & IO & 7 & - \\
\hline cf & N. farcinica & -1 & - & I & 0 & -2 & - & 2 & - & 一 & 3 & 3 & 16 & - & I4 & 12 & I I & - \\
\hline c & N. farcinica & 0 & - & 3 & 0 & I & 2 & - & - & - & - & 2 & 一 & - & - & 0 & 9 & 一 \\
\hline 0 & $N$. as & 3 & -2 & - & - & - & - & - & - & - & - & 4 & - & - & - & 0 & - & 一 \\
\hline c & N. a & 3 & 2 & 3 & - & - & - & - & - & - & - & $\begin{array}{l}4 \\
2\end{array}$ & - & - & - & 12 & - & 一 \\
\hline cf 787 & N. blackwellii & 2 & - & I & 2 & 2 & 3 & - & - & 一 & - & 一 & - & - & - & - & - & 一 \\
\hline RS $80^{\circ}$ & Nocardia sp. & 4 & 5 & 2 & 3 & 3 & 3 & 2 & 4 & 2 & 一 & - & 13 & - & 28 & 17 & 9 & 18 \\
\hline $\operatorname{cf} 678$ & N. far & 12 & - & I I & 14 & 14 & 16 & 一 & - & - & 一 & 13 & - & -2 & 9 & 10 & 14 & I I \\
\hline cf 746 & $N$. farcinica & 15 & - & - & - & - & - & - & 一 & 一 & 一 & - & -2 & - & 10 & 一 & - & 一 \\
\hline cf 6 & N. far & 13 & - & 6 & I I & I I & I4 & 一 & - & - & - & 28 & 9 & IO & - & $2 I$ & I 2 & 14 \\
\hline $\mathbf{R}$ & $N$. ast & 13 & $I I$ & I I & 13 & 10 & I 2 & IO & 10 & I2 & - & $r_{7}$ & 10 & 一 & 21 & - & 9 & 13 \\
\hline cf 809 & $N$. asteroides & 3 & - & 6 & 6 & 7 & II & 9 & - & 一 & 一 & 9 & I4 & - & 12 & 9 & - & 9 \\
\hline RS I I 7 & N. brasiliensis & 14 & - & - & - & - & 一 & - & - & - & - & 18 & I I & - & I4 & $I_{3}$ & 9 & - \\
\hline
\end{tabular}

* $\mathrm{RS}=$ purified sensitin. $\quad \dagger \mathrm{cf}=$ heat-sterilized culture filtrate. 
foal respectively, are also included in this group. This also applies to the sensitin of strain 745 , isolated from man, and to strain 650 , of unknown source.

Sensitins from three other strains $(678,746,677)$ designated Nocardia farcinica on receipt cannot be included in this group (spd $=6-16 \mathrm{~mm}$ ), but two of them (cf 678 , cf 746) can be grouped together (spd $=-2 \mathrm{~mm}$ ).

Sensitin from strain 80 shows spd $\leqslant 3 \mathrm{~mm}$. when compared with 6 of the sensitins in the main group and spd $=4-5 \mathrm{~mm}$. when compared with the sensitins of three strains in this group. (The spd between RS 80 and RS 84 reported previously (Magnusson, I962) is not correct, because of an error in calculation.) Therefore this sensitin 80 cannot be included in the main group by the criterion mentioned above.

Sensitins from all $\mathrm{I} 4$ strains show spd values varying from 3 to $2 \mathrm{I} \mathrm{mm}$. when compared with sensitins of Nocardia asteroides strain 8I, N. asteroides strain 809 and $N$. brasiliensis strain 117 , and therefore none of these preparations are grouped together.

The spd between sensitins of Nocardia asteroides strain 8I and $N$. asteroides strain 809 is $9 \mathrm{~mm}$.

\section{Classification of the strains on the basis of sensitin specificity}

On the basis of the specificity differences of the sensitins and with the criteria for their utilization in classification used earlier (Magnusson et al. 1961; Magnusson, 1962), the strains can be classified as follows: strains $84,85,650,745,749,750,75 \mathrm{I}$, $752,753,787$ as Nocardia farcinica; strains 678 and 746 as Nocardia sp.; strain 677 as Nocardia sp. and strain 80 as Nocardia sp.

\section{DISCUSSION}

The relationship between the strains found in this work by an immunological method can be supported by only a few results obtained by other methods. However, the method used here has given reproducible and reliable results in studies of more than 250 strains of mycobacteria. The relationships found between mycobacteria by this method have been confirmed by observations of the cultural, physiological and biochemical characteristics of those strains made in other laboratories. Identification at species level of a test strain by this method has been possible when an spd value of $<3 \mathrm{~mm}$. between sensitin of a reference strain belonging to a known species and the test strain has been found. SPD values of 3 or $4 \mathrm{~mm}$. have generally been considered inconclusive. These observations with mycobacteria have contributed to the following evaluation of the present results.

With one exception (strain 80 ) clear results have been obtained with all the 17 strains. Strain 80 has been classified as Nocardia asteroides (Dr Ruth Gordon, personal communication).

Ten of the strains, including the type strain of Nocardia farcinica (752) and 4 other strains $(749,750,751,753)$ previously identified as $N$. farcinica, form one group. Strains $749,750,75 \mathrm{I}$ were isolated from cattle with farcy and identified on the basis of their morphology and biochemical properties (Perpezat, Mariat, Destombes \& Thomé, 1963). The five other members of this group are strains $84,85,650,745,787$.

Strains 84 and 85 were identified as Nocardia asteroides when originally isolated from the placenta of a cow and from a dog, respectively (Fey, Holm \& Teuscher, 1954). 
Strain 650 was given by Professor N. F. Conant, North Carolina, U.S.A. Although its original source could not be traced, it cannot be the same isolate as any of the strains labelled Nocardia farcinica, since these strains were not kept in Conant's laboratory at the time when strain 650 was sent to the National Collection of Type Cultures, London (Professor N. F. Conant, personal communication).

Strain 745 originated from a human patient (Bergström, Edebo, Fors \& Tegner, 1966). In the report describing its isolation, the strain was repeatedly referred to as Nocardia asteroides, although it was also mentioned that it had been identified as $N$. farcinica by the present writers.

Strain 787 has been classified as Actinomyces blackwellii by Erikson (1935); it is characterized by its medium growth consistency, good formation of aerial mycelium with frequent angular branching, no soluble pigment on protein media, no liquefaction of gelatine and no action on milk (Erikson, 1935). This description is based on the study of the properties of a single strain (787). Schneidau \& Shaffer could neither distinguish this strain from 6 strains designated Nocardia asteroides in cultural studies (1957) nor by use of a slide agglutination test (1960).

Strains 650 and 787 have been classified as Nocardia asteroides by Gordon \& Mihm (1957). The same applies to strains 84 and 85 (Dr Ruth Gordon, personal communication). As mentioned in the Introduction, Gordon \& Mihm (I959) could distinguish neither the type strain of $N$. farcinica (strain 752) nor strain 753 from a series of strains which those authors called $N$. asteroides. In addition to strains $8 \mathrm{I}$ and 809 which were clearly distinguishable in the present work from the group of ro strains $\left(\mathrm{spd}=3^{-1} 3 \mathrm{~mm}\right.$.) and from each other $(\mathrm{spd}=9)$, the latter also included others which can be distinguished from this group, represented by strain 84 (unpublished data). These observations definitely do not support the opinion expressed by Gordon $\&$ Mihm (1962) that $N$. farcinica and $N$. asteroides are two different names for the same species.

It would appear justifiable to classify the Io strains in the largest group only as Nocardia farcinica. In consequence, $N$. blackwellii and Actinomyces blackwellii are subjective synonyms of $N$. farcinica. The three remaining strains labelled $N$. farcinica $(677,678,746)$ are quite distinct from the group of Io strains in the present study. On the basis of the present findings, the writers consider strains 678 and 746 form one separate species and 677 another.

Six strains classified in this work as Nocardia farcinica $(84,85,650,752,753,787)$ have been examined by the methods described by Gordon \& Mihm (1962). All of them grew at $50^{\circ}$ and four $(84,85,650,787)$ were able to ferment rhamnose (Dr Ruth Gordon, personal communication). Among 8 other strains which were classified as $N$. asteroides according to Gordon \& Mihm's criteria and which, according to the present method, are distinguishable from $N$. farcinica (unpublished data), none showed both the above-mentioned characteristics (Dr Ruth Gordon, personal communication). Of 142 strains classified as $N$. asteroides, only $21 \%$ grew at $50^{\circ}$ (Gordon \& Mihm, 1962). The strains classified as $N$. farcinica in the present work (except strain 749) have a higher growth rate at $45^{\circ}$ than other strains classified as $N$. asteroides by Gordon \& Mihm's criteria. It may thus be possible to demonstrate characteristic physiological and biochemical features of $N$. farcinica strains and to differentiate between that species and $N$. asteroides by conventional methods also. However, further studies are required. 
It was reported earlier that 29 out of 30 strains of Nocardia asteroides were ureasepositive, in contrast to 14 strains of $N$. farcinica, including 749, 750 and $75 \mathrm{I}$ which were urease-negative (Mariat, 1963). Strains 752 (the type strain of $N$. farcinica) and 753 are both urease-positive (unpublished observation). Thus the urease reaction may not always be of help in the distinction between $N$. farcinica and $N$. asteroides.

According to Waksman (1957), strains of Nocardia farcinica are transmissible to guinea pigs, cattle and sheep but not to rabbit, dogs or horses. However, two of the strains identified as $N$. farcinica in the present work $(84,85)$ were reported to be transmissible to rabbits (Fey et al. 1954). As mentioned earlier, one of these two strains was isolated from a dog, and strain 787 , which has also been identified as $N$. farcinica in the present work, was originally isolated from a foal (Erikson, 1935). Therefore, according to the present findings, the description of $N$. farcinica given by Waksman (1957) and based on two strains only, should apparently be revised as regards the pathogenicity of the species. It is remarkable that strain 745 , identified as $N$. farcinica in the present work, was isolated from a human patient (Bergström, et al. 1966). This is apparently the first known case of human infection caused by $N$. farcinica. Other such cases may be found, particularly where the causal agent has been identified as $N$. asteroides and where the isolate has been rhamnose-positive and able to multiply at $50^{\circ}$. Strains of $N$. farcinica isolated from human patients may also be identified among the strains which could not be distinguished from $N$. blackwellii in the study reported by Schneidau \& Shaffer (1960).

The writers are most grateful to Dr L. Edebo, Department of Bacteriology, University of Uppsala, Sweden; Dr Ruth Gordon, Institute of Microbiology, Rutgers University, New Brunswick, New Jersey, U.S.A.; and Dr N. M. McClung, Department of Bacteriology, University of Georgia, Athens, Georgia, U.S.A., for providing cultures.

\section{REFERENCES}

Bergström, R., Edebo, L., Fors, B. \& Tegner, K.-B. (I966). Systemic Nocardia infection. Scand. J. resp. Dis. 47, 75.

Blanchard, R. (I 896). Parasites végétaux a l'exclusion des bactéries. In Traité de pathologie générale. Ed. by Ch. Bouchard, vol. 2, p. 8 I I. Paris: Masson.

EPPINGER, H. (1891). Ueber eine neue, pathogene Cladothrix und eine durch sie hervorgerufene Pseudotuberculosis (cladothrichica). Beitr. path. Anat. 9, 287.

ERIKSON, D. (1935). The pathogenic aerobic organisms of the Actinomyces group. Spec. Rep. Ser. med. Res. Coun. no. 203, pp. 25, $26,37$.

Fey, H., Holm, P. \& Teuscher, E. (1954). Nocardiosen. Kasuistische Mitteilung über einen Fall von septischer Nocardiose beim Hund und zwei Fälle von Nocardia-Abortus beim Rind. Schweizer Arch. Tierheilk. 96, 642.

Gordon, R. E. \& MirM, J. M. (1957). A comparative study of some strains received as Nocardiae. J. Bact. 73, 15.

Gordon, R. E. \& Mrнm, J. M. (1959). A comparison of Nocardia asteroides and Nocardia brasiliensis. J. gen. Microbiol. 20, 129.

Gordon, R. E. \& Miнm, J. M. (1962). The type species of the genus Nocardia. J. gen. Microbiol. 27, r.

MAGnusson, M. (196I) Specificity of mycobacterial sensitins. I. Studies in guinea-pigs with purified 'Tuberculin' prepared from mammalian and avian tubercle bacilli, Mycobacterium balnei and other acid-fast bacilli. Am. Rev. resp. Dis. 83, 57.

Magnusson, M. (1962). Specificity of sensitins. III. Further studies in guinea-pigs with sensitins of various species of Mycobacterium and Nocardia. Am. Rev. resp. Dis. 86, 395. 
MAGNusson, M. (1965). Classification and identification of mycobacteria by an immunological procedure based on the specificity of the delayed type reaction. Publ. Faculté Sci. Université J. E. Purkyne, Brno, Serie K 35, 376.

MAGNusson, M., ENGBeK, H. C. \& BenTzon, M. W. (196I). Specificity of mycobacterial sensitins. II. Studies in guinea-pigs with purified sensitin prepared from unclassified acid-fast bacilli. Am. Rev. resp. Dis. 83, 69.

Magnusson, M., Guld, J., Magnus, K. \& WaAler, H. (1958). Diluents for stabilization of Tuberculin. Bull. Wld Hlth Org. 19, 799.

Mariat, F. (I963). Activité uréasique des Actinomycétes aérobies pathogenes. Annls Inst. Pasteur, Paris 105, 795.

NoCARD, E. (I888). Note sur la maladie des bœufs de la Guadeloupe connue sous le nom de farcin. Annls Inst. Pasteur, Paris 2, 293.

Perpezat, A., Mariat, F., Destombes, P. \& Thome, M. (1963). Importance du farcin chez le Zébu du Tchad. Bull. Soc. Path. exot. 56, 375.

Schneidau, J. D. Jun. \& Shaffer, M. F. (I957). Studies on Nocardia and other actinomycetales. I. Cultural studies. Am. Rev. Tuberc. 76, 770.

Schneidau, J. D. Jun. \& Shaffer, M. F. (I960). Studies on Nocardia and other actinomycetales. II. Antigenic relationships shown by slide agglutination tests. Am. Rev. resp. Dis. 82, 64.

Silvestri, L., TURRI, M., HiLl, L. R. \& GilARDI, E. (1962). A quantitative approach to the systematics of actinomycetes based on overall similarity. Symp. Soc. gen. Microbiol. 12, 333.

Sneath, P. H. A. \& Skerman, V. B. D. (1966). A list of type and reference strains of bacteria. Int. J. System. Bact. 16, I.

Trevisan, V. (1889). I Generi e le Specie delle Batteriacee. Milano: Zanaboni e Gabuzzi. Reproduced in Int. Bull. Bact. Nomencl. Taxon. (1952) 2, 13.

Waksman, S. A. (1957). Actinomycetaceae Buchanan. In Bergey's Manual of Determinative Bacteriology, 7th ed., p. 718. Baltimore: The Williams and Wilkins Company.

ØRSKov, J. (1923). Investigations into the morphology of the ray fungi, p. 78, 96. Thesis. Copenhagen: Levin and Munksgaard. 